\title{
Effects of Peripartum Propylene Glycol Supplementation on Nitrogen Metabolism, Body Composition, and Gene Expression for the Major Protein Degradation Pathways in Skeletal Muscle in Dairy Cows
}

\author{
G. E. Chibisa, G. N. Gozho, A. G. Van Kessel, A. A. Olkowski, and T. Mutsvangwa ${ }^{1}$ \\ Department of Animal and Poultry Science, University of Saskatchewan, Saskatoon, Canada S7N 5A8
}

\begin{abstract}
Early-lactating dairy cows mobilize body protein to provide amino acids that are directed toward gluconeogenesis and milk protein synthesis. Propylene glycol (PG) is a precursor of ruminal propionate, and feeding PG has been reported to improve energy supply by increasing blood glucose. Our hypothesis was that feeding PG could spare body protein by providing an alternative source of carbon for gluconeogenesis. The major objectives of this study were 1) to delineate the effects of pre- and postpartum PG supplementation in transition dairy cows on whole-body nitrogen balance, urinary 3-methylhistidine (3-MH) excretion, body composition, and gene expression profiles for the major protein degradation pathways in skeletal muscle; and 2) to characterize the changes in body protein metabolism during the periparturient period. Sixteen pregnant cows (7 primiparous and 9 multiparous) were paired based on expected calving dates and then randomly assigned within each pair to either a basal diet (control) or basal diet plus $600 \mathrm{~mL} / \mathrm{d}$ of PG. Diets were fed twice daily for ad libitum intake, and PG was fed in equal amounts as a top dress from $\mathrm{d}-7$ to $\mathrm{d} 45$. All measurements were conducted at 3 time intervals starting at $\mathrm{d}-14 \pm 5, \mathrm{~d} 15$, and $\mathrm{d} 38$ relative to calving. Propylene glycol had no effect on whole-body $\mathrm{N}$ balance, urinary 3-MH excretion, or body composition. However, $\mathrm{N}$ balance was lower at $\mathrm{d} 15$ and 38 , compared with $\mathrm{d}-14$. Urinary excretion of 3-MH was lower at $d-14$ than at $d 15$ and 38. Supplemental PG had no effect on body weight (BW) and all components of empty BW. On average, cows fed both diets mobilized $19 \mathrm{~kg}$ of body fat and $14 \mathrm{~kg}$ of body protein between d -14 and d 38. Supplemental PG had no effect on mRNA abundance in skeletal muscle for m-calpain, and the $14-\mathrm{kDa}$ ubiquitin-carrier protein E2 (14-kDa E2) and
\end{abstract}

Received December 5, 2007.

Accepted May 2, 2008.

${ }^{1}$ Corresponding author: tim.mutsvan@usask.ca proteasome 26S subunit-ATPase components of the ubiquitin-mediated proteolytic pathway; however, PG supplementation downregulated mRNA expression for $\mu$-calpain at d 15, and tended to downregulate mRNA expression for ubiquitin at $d 15$ and 38 . Relative to calving, mRNA abundance for $\mathrm{m}$ - and $\mu$-calpain, ubiquitin, and $14-\mathrm{kDa}$ E2 were greater at d 15 compared with d -14 and $d$ 38. In summary, these results indicate that transitional effects on whole-body metabolism and gene expression for the $\mathrm{Ca}^{2+}$-dependent and ubiquitinmediated proteolytic pathways in skeletal muscle were more pronounced than those elicited by PG supplementation.

Key words: dairy cow, nitrogen metabolism, propylene glycol, protein degradation pathway

\section{INTRODUCTION}

Typically, voluntary feed intake in a dairy cow declines by 30 to $40 \%$ around calving compared with intake during the early dry period (Grummer, 1993). Invariably, the early-lactating cow faces a glucose and amino acid deficit (Phillips et al., 2003). To ameliorate this nutrient deficit, body adipose and protein reserves are mobilized to support the energy requirements for high milk production in early lactation. Although body fat depots are recognized as the major source of energy reserves, the catabolism of both body fat and protein contribute to nutrient requirements in early lactation (NRC, 2001). During this period, body fat mobilization ranges from 41 to $90 \mathrm{~kg}$ (Erdman and Andrew, 1989), and protein mobilization ranges from 21 to $24 \mathrm{~kg}$ (Komaragiri and Erdman, 1997; Komaragiri et al., 1998). Therefore, in addition to being in a negative energy balance, dairy cows experience a negative nitrogen $(\mathrm{N})$ balance in early lactation (Plaizier et al. 2000a).

Body protein mobilization is driven by the overwhelming need to supply amino acids for hepatic gluconeogenesis and for milk protein synthesis during early lactation (Bauman and Currie, 1980). Propionate is the major precursor for gluconeogenesis (Drackley et al., 2001); however, limited feed intake during early 
lactation limits ruminal propionate supply to the liver, raising the requirement for alternative gluconeogenic precursors. Besides amino acids, there is an increased contribution of lactate, pyruvate, and glycerol to hepatic gluconeogenesis, which augment the limited propionate supply (Lomax and Baird, 1983). Although skeletal muscle is the primary labile source of amino acids, only a few studies have investigated protein metabolism in this tissue during lactation (Meijer et al., 1995; Komaragiri et al., 1998; Phillips et al., 2003). Skeletal muscle protein mass has been shown to decrease in early-lactating dairy cows (Komaragiri et al., 1998; Phillips et al., 2003); however, to our knowledge, the major protein degradation pathways that are responsible for skeletal muscle proteolysis in transition dairy cows have not been characterized.

Although the mobilization of protein reserves is necessary to augment the inadequate dietary supply of energy and protein, excessive mobilization can lead to an increased incidence of metabolic disorders, and poor reproductive and lactational performance (Drackley, 1999). Various approaches to optimize postpartum nutrient supply and, thus, minimize the mobilization of body reserves, have been investigated. These include altering dietary protein (Komaragiri and Erdman, 1997; Phillips et al., 2003) and amino acid (Phillips et al., 2003) supply, and feeding supplemental fat (Komaragiri et al., 1998; DeFrain et al., 2005), or gluconeogenic precursors (DeFrain et al., 2005). However, fewer studies have reported dietary effects on pre- and postpartum body protein catabolism, and there is still a limited understanding of the mechanisms involved in this adaptation (Phillips et al., 2003). Propylene glycol $(\mathbf{P G})$ is a precursor of ruminal propionate that can be rapidly absorbed from the rumen for gluconeogenesis in the liver (Nielsen and Ingvartsen, 2004), and it is routinely added to transition cow rations. Feeding PG has been shown to increase plasma glucose (Miyoshi et al., 2001) and to decrease plasma NEFA and BHBA concentrations (Grummer et al., 1994). However, the effect of PG in sparing body protein by providing an alternative energy source in transition dairy cows is unknown. Therefore, we hypothesized that body protein loss during early lactation in dairy cows can be attenuated by administering PG in pre- and postpartum diets. The major objectives of this study were 1) to delineate the effects of pre- and postpartum PG supplementation in transition dairy cows on whole-body $\mathrm{N}$ balance, urinary 3-methylhistidine (3-MH) excretion, body composition, and gene expression profiles for the major protein degradation pathways in skeletal muscle; and 2) to characterize the changes in body protein metabolism during the periparturient period.

\section{MATERIALS AND METHODS}

\section{Animals and Experimental Design}

Sixteen pregnant cows (7 primiparous and 9 multiparous) housed in individual tie-stalls were used in a randomized complete block design. Animals were paired based on expected calving dates, and randomly assigned within each pair to 1 of 2 dietary treatments. The experiment was carried out from May to December 2006. All measurements and sample collections were conducted at 3 time intervals starting at $d-14 \pm 5, d$ 15 , and $d 38$ relative to calving. The first measurement period $(\mathrm{d}-14 \pm 5)$ was the pretreatment period. Experimental procedures used were in accordance with the Canadian Council of Animal Care (1993) guidelines.

\section{Experimental Treatments and Cow Management}

Treatments consisted of a basal diet (control) or the basal diet plus $600 \mathrm{~mL} / \mathrm{d}$ of PG (Glycol-P, Vétoquinol, Quebec City, Canada). Supplementation with PG started at $\mathrm{d}-7$ after the initial measurement period and ended at $d 45$, relative to calving. The same basal diet was fed as a TMR during the pre- and postpartum periods, and the ingredient and chemical composition of the diet is presented in Table 1. Barley silage and hay that were fed throughout the experiment were from the same source, so there was minimal variation in forage composition. Cows were fed daily for ad libitum intake for minimal orts $(<5 \%)$ at 0830 and $1600 \mathrm{~h}$. At each feeding, $300 \mathrm{~mL}$ of $\mathrm{PG}$ was top-dressed onto the TMR and thoroughly mixed with the top portion of the TMR before the feed was offered to the cows. Rumensin was not included in the experimental diet.

\section{Sample Collection}

Feed intake and orts were recorded daily throughout the experiment. On 3 consecutive days within each measurement period, TMR and orts were collected daily and composited by cow. All samples were stored at $-20^{\circ} \mathrm{C}$ for later analysis. Cows were milked twice daily at 0500 and $1500 \mathrm{~h}$, and milk weights were recorded daily throughout the experiment. During each measurement period, milk samples were collected on 3 consecutive days from the morning and afternoon milkings into plastic vials with 2-bromo-2-nitropropane-1-2-diol as a preservative. Milk samples were pooled based on daily milk yield for each cow. Pooled milk samples were analyzed for CP, fat, and lactose using a near infrared analyzer (Foss System 4000, Foss Electric, Hillerød, Denmark). 
Table 1. Ingredient and chemical composition of basal diet with or without propylene glycol

\begin{tabular}{lc}
\hline Item & \\
\hline Ingredient composition, \% of DM basis & \\
Barley silage & 32.4 \\
Hay & 16.3 \\
Dehydrated alfalfa & 7.8 \\
Barley & 17.1 \\
Wheat & 1.0 \\
Oats & 1.5 \\
Molasses & 0.6 \\
Soybean meal & 8.1 \\
Canola meal & 7.2 \\
Wheat distillers dried grains & 2.2 \\
Corn gluten meal & 1.5 \\
Golden flakes ${ }^{1}$ & 0.3 \\
Canola oil & 0.5 \\
Mineral-vitamin mix ${ }^{2}$ & 2.3 \\
Niacin-magnesium mix ${ }^{3}$ & 0.04 \\
Cobalt-iodized salt & 0.5 \\
Sodium bicarbonate & 0.5 \\
Ground limestone & 0.04 \\
Dynamate & \\
Chemical composition & 0.2 \\
DM, \% & \\
OM, \% of DM & 55.4 \\
CP, \% of DM & 92.6 \\
Fat, \% of DM & 17.3 \\
NDF, \% of DM & 2.8 \\
ADF, \% of DM & 38.2 \\
NE, Mcal/kg & 23.4 \\
\hline Dried fat supplement & 1.63 \\
\hline
\end{tabular}

${ }^{1}$ Dried fat supplement (Malaysian palm oil) distributed in western Canada by Prairie Micro-Tech Inc. (Regina, Saskatchewan, Canada).

${ }^{2}$ Supplied $22 \mathrm{mg}$ of manganese, $30 \mathrm{mg}$ of zinc, $8 \mathrm{mg}$ of copper, $0.2 \mathrm{mg}$ of selenium, 5,278 IU of vitamin A, $864 \mathrm{IU}$ of vitamin $\mathrm{D}_{3}$, and $14 \mathrm{IU}$ of vitamin E per kilogram of control diet. The mix also contributes $0.07 \%$ magnesium, $0.23 \%$ calcium, $0.12 \%$ phosphorus, $0.11 \%$ sodium, and $0.18 \%$ chloride to the control diet (Federated Cooperatives Ltd., Saskatoon, Canada).

${ }^{3}$ Supplied $0.13 \mathrm{~g}$ of niacin and $0.04 \mathrm{~g}$ of magnesium per kilogram of control diet.

${ }^{4}$ Supplied $0.07 \%$ sulfur, $0.06 \%$ potassium, and $0.04 \%$ magnesium per kilogram of control diet (International Minerals and Chemical Corp., Mundelein, IL).

${ }^{5}$ Calculated using NRC (2001).

On d 1 of each measurement period, body composition was determined using the urea dilution technique, as described by Agnew et al. (2005). Following body composition measurements, cows were fitted with indwelling bladder catheters (Bardex Foley catheter, 75mL capacity balloon; C. R. Bard Inc., Covington, GA) for total urine collection. Nitrogen balance, total-tract nutrient digestibility, and urinary 3-MH excretion determinations were conducted from d 2 to 7 . Daily total urine output was acidified with $150 \mathrm{~mL}$ of concentrated $\mathrm{HCl}$. On each total collection day, $2.5 \%$ of output was drawn, pooled for each cow during each collection period, and stored at $-20^{\circ} \mathrm{C}$ until analyzed for total $\mathrm{N}$ and $3-\mathrm{MH}$. Feces were collected into large steel trays which were positioned over the gutter behind each stall. Feces were mixed thoroughly for each cow and $5 \%$ of daily output was sampled and stored at $-20^{\circ} \mathrm{C}$ for later chemical analysis. On d 8, muscle tissue was obtained by needle biopsy from the longissimus muscle (m. longissimus lumborum), as described by Meijer et al. (1995). The collected tissue samples were immediately frozen in liquid $\mathrm{N}_{2}$ and stored at $-70^{\circ} \mathrm{C}$ pending RNA analysis. A blood sample was collected from each cow every Friday at $0900 \mathrm{~h}$ via tail venipuncture into a serum tube and a lithium heparin-coated tube. Blood samples were centrifuged at $1,800 \times g$ for $15 \mathrm{~min}$ to obtain plasma and serum, which were then stored at $-20^{\circ} \mathrm{C}$.

\section{Sample Analyses}

Frozen feed, orts, urine, and fecal samples were thawed at room temperature (approximately $20^{\circ} \mathrm{C}$ ) and pooled per total collection period for each cow. All samples (except urine) were oven-dried at $55^{\circ} \mathrm{C}$ for $48 \mathrm{~h}$ to determine DM. Samples were then ground through a 1-mm screen using a Christy-Norris mill (Christy and Norris Ltd., Chelmsford, UK), and analyzed for Kjeldahl N, ether extract (AOAC, 1990), ADF, and NDF with sulfite and heat-stable a-amylase (Van Soest et al., 1991). Total $\mathrm{N}$ in urine was determined using the macro-Kjeldahl procedure (AOAC, 1990).

Urinary 3-MH was quantified by using reverse-phase HPLC. A sample of pooled urine from total collections $(475 \mu \mathrm{L})$ was mixed with $25 \mu \mathrm{L}$ of a $5 \%$ (wt/vol) solution of L-ornithine hydrochloride as an internal standard. Equal volumes $(500 \mu \mathrm{L})$ of the urine-internal standard mixture and a solution of $0.7 M$ perchloric acid were combined and centrifuged at $18,000 \times g$ for $5 \mathrm{~min}$. The supernatant was mixed with an equal volume of 0.25 $M$ potassium hydroxide to neutralize the sample, and centrifuged at $18,000 \times g$ for $5 \mathrm{~min}$. A portion of the supernatant $(50 \mu \mathrm{L})$ was then derivatized as described by Min et al. (1992). Separation of compounds was done on a reverse-phase column [Luna $2.5 \mu \mathrm{m} \mathrm{C18} \mathrm{(2)-}$ HST, $100 \times 3.0 \mathrm{~mm}$, Phenomenex, Torrance, CA] using an Agilent HPLC system (Agilent 1100 series, Agilent Technologies, Waldbronn, Germany). The mobile phase consisted of 2 buffers (A and B). Buffer A consisted of $12.5 \mathrm{~m} M$ potassium phosphate and $5 \% \mathrm{MeOH}(\mathrm{pH} 9)$, and buffer $\mathrm{B}$ consisted of $12.5 \mathrm{mM}$ potassium phosphate and $20 \%$ acetonitrile $(\mathrm{pH} 9)$. The gradient was A to $\mathrm{B}$ in $60 \mathrm{~min}$, which was followed by a 5 -min column wash using $75 \%$ acetonitrile. A flow rate of $0.75 \mathrm{~mL} /$ min was used and the 3-MH derivative was detected using a Shimadzu fluorescence detector (RF-551, Spectrofluorometric detector, Shimadzu, Columbia, MD) set at an excitation wavelength of $330 \mathrm{~nm}$ and emission wavelength of $450 \mathrm{~nm}$. 
Table 2. Quantitative real-time PCR primers

\begin{tabular}{llll}
\hline & & & \multicolumn{2}{c}{ Primer sequence } \\
\cline { 3 - 4 } Gene & $\begin{array}{l}\text { GenBank } \\
\text { accession no. }\end{array}$ & Forward $\left(5^{\prime}-3^{\prime}\right)$ & Reverse $\left(5^{\prime}-3^{\prime}\right)$ \\
\hline$\mu$-Calpain & AF248054 & TTCAGGCCAATCTCCCCGACG & GATGTTGAACTCCACCAGGCCCAG \\
m-Calpain & XM_864105 & GGAGGAAGAGGACGAGGAC & TTGCTGAGGTGGATGTTGG \\
Ubiquitin & NM_174133 & GCCGCACTCTTTCTGATTACAAC & CGTTCTCGATGGTGTCACTGG \\
14-kDa Ubiquitin-carrier protein E2 & BC109502 & TGGACCACAAGGAACACCGTATG & TGCAGCGTCACCATTGAGAGG \\
Proteasome 26S subunit, ATPase & BC102595 & TGTCCGAGAGAATCGCTACA & TAGGTTTGGGGAAAGAGGCT \\
GAPDH & NM_001034034 & GCCTGGAGAAACCTGCCAAGTATG & TGGTCCTCAGTGTAGCCTAGAATGC \\
\hline
\end{tabular}

Muscle tissue samples were pulverized with a mortar and pestle under liquid nitrogen. A 30-mg subsample was then used for total RNA extraction using an RNAeasy Mini Kit (Qiagen, Mississauga, Ontario, Canada). The final step of the extraction process involved RNase-free DNase (Qiagen) digestion. The extracted RNA was quantified with PicoGreen (Molecular Probes, Eugene, OR) using a fluorometer (Fluoroscan Ascent FL, Thermo Labsystems, Waltham, MA). Extracted RNA (45 ng) was reverse-transcribed to cDNA using SuperScript III First-Strand Synthesis System (Invitrogen, Carlsbad, CA). Gene transcript abundance was determined by real-time quantitative PCR (qPCR; iCycler iQ Real-Time PCR detection system, BioRad) using SYBR Green fluorescence detection. The primers (Table 2) used for m-calpain, ubiquitin, and 14-kDa ubiquitin-carrier protein E2 (14-kDa E2) were designed using Beacon Designer (Premier Biosoft International, Palo Alto, CA), whereas the primers used for GAPDH (Mena et al., 2002), $\mu$-calpain (Juszczuk-Kubiak et al., 2004), and proteasome 26S subunit, ATPase (Guo et al., 2005) were reported previously. Primer specificity was confirmed by sequencing (data not shown) of the relevant PCR product following standard PCR amplification of cDNA from bovine muscle using conditions similar to qPCR (Table 3). The real-time qPCR reaction mixture used for each gene consisted of $12.5 \mu \mathrm{L}$ of Platinum SYBR Green qPCR SuperMix-UDG (Invitrogen, Burlington, Ontario, Canada), $0.5 \mu \mathrm{L}$ of each primer $(25 \mu M)$, and $1.0 \mu \mathrm{L}$ of template cDNA, made up to $25 \mu \mathrm{L}$. The qPCR amplification conditions specific for each gene are summarized in Table 3. Transcript abundance for each gene was determined by interpolating the threshold cycle for cDNA against a standard curve constructed from gel-purified amplicons over the range of $10^{1}$ to $10^{7}$ copies (copy number calculated based on molecular weight). To prepare standard curves for each target gene, bovine muscle cDNA was amplified using relevant qPCR primers, gel extracted (Invitrogen) and quantified using PicoGreen (Molecular Probes). The results are presented as target gene transcript abundance normalized to GAPDH transcript abundance. Expression of GAPDH mRNA in equal amounts of total RNA indicated that GAPDH in skeletal muscle was stable and unaffected by the experimental conditions that were employed.

Blood plasma harvested during body composition measurements and that from weekly blood samplings were used to determine plasma urea N (PUN) by the diacetyl monoxime method. Plasma samples from the weekly blood samples were also used to determine blood glucose colorimetrically using the glucose oxidase method (Procedure No. 1070; Stanbio Laboratory, Boerne, TX) and insulin using RIA. The insulin analytical procedure involved an initial radio-iodination step (Greenwood et al., 1963) using a crystalline bovine insulin (lot no. 615-70N-80, Lilly Research Laboratories, Indianapolis, IN) as a standard, before analysis of the radio-iodinated insulin by double-antibody RIA (Brockman, 1979). The intra- and interassay coefficients of variation for determination of plasma insulin were 7.6 and 5.9\%, respectively. Serum NEFA and BHBA

Table 3. Quantitative real-time PCR conditions ${ }^{1}$

\begin{tabular}{|c|c|c|c|c|c|c|}
\hline Gene name & \multicolumn{2}{|c|}{ Denaturation step (40×) } & \multicolumn{2}{|c|}{ Annealing step (40×) } & \multicolumn{2}{|c|}{ Extension step $(40 \times)$} \\
\hline GAPDH & 95.0 & 30 & 62.0 & 30 & 72.0 & 30 \\
\hline m-Calpain & 95.0 & 30 & 60.0 & 30 & 72.0 & 30 \\
\hline Ubiquitin & 95.0 & 30 & 55.0 & 30 & & \\
\hline 14-kDa Ubiquitin-carrier protein E2 & 95.0 & 30 & 56.0 & 30 & & \\
\hline
\end{tabular}

${ }^{1} 40 \times=40$ cycles; $\mathrm{T}=$ temperature. 
were analyzed by the Animal Health Laboratory at the University of Guelph using a Hitachi 911 automated analyzer (Roche, Laval, Quebec, Canada).

\section{Calculations and Statistical Analysis}

Energy balance (EB) was calculated as net energy intake (NEI) - net energy requirement (NER). Net energy intake was determined as average daily DMI $\times$ the calculated $\mathrm{NE}_{\mathrm{L}}$ value of the diet. For PG-fed cows, this calculation of NEI included the estimated energy contribution of PG (2.83 Mcal/d). For prefresh cows, NER was calculated as $\mathrm{NE}_{\mathrm{M}}$ + net energy for pregnancy $\left(\mathrm{NE}_{\mathrm{P}}\right)$, where $\mathrm{NE}_{\mathrm{M}}$ and $\mathrm{NE}_{\mathrm{P}}(\mathrm{Mcal} / \mathrm{d})$ where calculated using NRC (2001) equations. For lactating cows, NER was calculated as $\mathrm{NE}_{\mathrm{M}}+\mathrm{NE}_{\mathrm{L}}$. Net energy for lactation $(\mathrm{Mcal} / \mathrm{d})$ was calculated as $(9.29 \times$ fat yield/d $)+(5.71 \times$ protein yield/d) $+(3.95 \times$ lactose yield/d; NRC, 2001$)$.

All pretreatment data $(\mathrm{d}-14 \pm 5)$ were analyzed using a $t$-test to determine if there were any dietary treatment differences. The pretreatment means for urine $\mathrm{N}$ were different; therefore, the pretreatment data were used as covariates. Feed intake and digestibility, blood metabolite, $\mathrm{N}$ balance data (except for urine $\mathrm{N}$ ), urinary $3-\mathrm{MH}$, body composition, and gene expression data were analyzed as a completely randomized block design with repeated measures using the PROC MIXED procedure (SAS Institute, 2004). The variance-covariance error structure with the lowest Akaike's and Bayesian information criteria was used for repeated measures analysis for each of the measurements. Treatment was considered as a fixed effect, and week of sampling (blood metabolites) or day (relative to calving) as the repeated measure. The correlation coefficient between empty body protein and urinary $3-\mathrm{MH}$ concentration was determined using PROC CORR (SAS Institute, 2004). Data on milk production and composition and changes in body composition were analyzed as a completely randomized block design using the PROC MIXED procedure (SAS Institute, 2004). Treatment, time, or treatment $\times$ time effects were declared significant at $P$ $<0.05$ and trends at $0.05 \leq P<0.10$.

\section{RESULTS AND DISCUSSION}

The ingredient composition and chemical analysis of the experimental diet are presented in Table 1 . The energy value of the diet was calculated to be $1.63 \mathrm{Mcal}$ of $\mathrm{NE}_{\mathrm{L}} / \mathrm{kg}$ (NRC, 2001), and dietary CP was determined to be $17.3 \%$ (DM basis). During the close-up phase of the experiment, the CP level was above NRC (2001) recommendations, whereas $\mathrm{NE}_{\mathrm{L}}$ density was within NRC (2001) recommendations. Current practice in the Dairy Unit at the University of Saskatchewan is to transition cows to a high-energy, high-protein diet during the close-up dry period, and this is becoming a common practice on dairy farms in western Canada. Dietary nutrient density is increased to promote ruminal adaptation, mitigate the decline in DMI of the prefresh cow, and limit the mobilization of body tissue in early lactation. Indeed, increasing the energy density (up to $1.73 \mathrm{Mcal}$ of $\mathrm{NE}_{\mathrm{L}} / \mathrm{kg}$; McNamara et al., 2003) or CP concentration (Phillips et al., 2003) has been demonstrated to improve DMI and milk production during the postpartum period.

Adding $P G$ to the diet had no effect $(P=0.22)$ on DMI; consequently, OM $(P=0.40), \mathrm{N}(P=0.51), \mathrm{ADF}$ $(P=0.62)$, and NDF $(P=0.57)$ intakes were also unaffected by treatment (Table 4). Propylene glycol supplementation has been shown not to alter DMI in earlylactating dairy cows (Miyoshi et al., 2001; Nielsen and Ingvartsen, 2004). Across dietary treatments, DMI was greater $(P<0.001)$ at $\mathrm{d} 15$ and 38 compared with $\mathrm{d}-14$. Postpartum DMI was greater $(P<0.001)$ at $\mathrm{d}$ 38 than at $d 15$ (Table 4 ). These changes in DMI were expected because the 3 -wk period preceding calving is characterized by a reduction in feed intake (McNamara et al., 2003); however, postpartum, there is a gradual increase in DMI that peaks around 75 DIM. The increase in DMI at d 15 and 38 also led to a concomitant increase $(P<0.001)$ in $\mathrm{OM}, \mathrm{ADF}$, and NDF intakes (Table 4).

Supplementing pre- and postpartum diets with PG tended to increase apparent DM $(P=0.06)$ and $\mathrm{OM}(P$ $=0.06)$ digestibility, and it increased $\mathrm{NDF}(P=0.03)$ digestibility, but had no effect on $\mathrm{N}(P=0.14)$ and $\mathrm{ADF}$ $(P=0.10)$ digestibility (Table 4$)$. In contrast to our observations, PG feeding did not affect diet digestibility in lactating cows (Cozzi et al., 1996). The greater diet digestibility for cows supplemented with $\mathrm{PG}$ in the present study is difficult to explain. Numerically, cows fed PG consumed 0.4 to $2.1 \mathrm{~kg} / \mathrm{d}$ less feed compared with control cows and it is possible that the lower feed intake could have resulted in a longer rumen retention time and, thus, increased diet digestion (Colucci et al., 1982). Across treatments, ADF digestibility was numerically greater $(P=0.08)$, and NDF digestibility was $4.85(P=0.01)$ and $4.21(P=0.02)$ percentage units greater before calving, compared with d 15 and 38 , respectively (Table 4). Similarly, changes in fiber digestion postpartum can partly be attributable to the effect of changes in DMI on rumen retention time. In the current study, average DMI (across treatments) increased by 51 and $94 \%$ at d 15 and 38, respectively, compared with d -14 .

Propylene glycol supplementation had no effect on plasma glucose $(P=0.93)$, insulin $(P=0.65)$, serum NEFA $(P=0.81)$, BHBA $(P=0.57)$, or PUN $(P=0.29)$ 
Table 4. The effect of propylene glycol (PG) administration on DM, OM, N, ADF, and NDF intake and apparent digestibility in transition dairy cows

\begin{tabular}{|c|c|c|c|c|c|c|}
\hline \multirow[b]{2}{*}{ Item } & \multicolumn{2}{|c|}{ Treatment } & \multirow[b]{2}{*}{ SEM } & \multicolumn{3}{|c|}{$P$-value ${ }^{1}$} \\
\hline & Control & $P G$ & & Trt & Time & Trt $\times$ Time \\
\hline $\mathrm{d}-14$ & 9.7 & 10.1 & 1.9 & & & \\
\hline d 15 & 15.2 & 14.7 & 1.9 & & & \\
\hline d 38 & 19.9 & 17.8 & 1.9 & & & \\
\hline $\begin{array}{l}\text { DM digestibility, \% } \\
\text { d }-14\end{array}$ & & & & 0.06 & 0.61 & 0.96 \\
\hline d 38 & 64.7 & 65.6 & 0.8 & & & \\
\hline OM intake, $\mathrm{kg} / \mathrm{d}$ & & & & 0.40 & $<0.001$ & 0.39 \\
\hline $\mathrm{d}-14$ & 9.0 & 9.4 & 1.8 & & & \\
\hline d 15 & 14.1 & 13.6 & 1.8 & & & \\
\hline $\mathrm{d} 38$ & 18.4 & 16.5 & 1.8 & & & \\
\hline OM digestibility, \% & & & & 0.06 & 0.47 & 0.97 \\
\hline $\mathrm{d}-14$ & 65.3 & 66.3 & 0.8 & & & \\
\hline d 38 & 506.7 & 465.1 & 30.1 & & & \\
\hline \multirow{2}{*}{$\begin{array}{l}\mathrm{N} \text { digestibility, } \% \\
\mathrm{~d}-14\end{array}$} & & & & 0.14 & 0.57 & 0.75 \\
\hline & 70.0 & 70.5 & 0.7 & & & \\
\hline d 15 & 69.1 & 69.9 & 0.7 & & & \\
\hline d 38 & 69.3 & 70.8 & 0.7 & & & \\
\hline ADF intake, kg/d & & & & 0.62 & $<0.0001$ & 0.25 \\
\hline $\mathrm{d}-14$ & 2.56 & 2.78 & 0.45 & & & \\
\hline d 15 & 3.59 & 3.48 & 0.48 & & & \\
\hline d 38 & 4.72 & 4.31 & 0.48 & & & \\
\hline \multirow{2}{*}{$\begin{array}{l}\text { ADF digestibility, } \% \\
\text { d }-14\end{array}$} & & & & 0.10 & 0.08 & 0.72 \\
\hline & 43.6 & 46.7 & 1.7 & & & \\
\hline d 15 & 38.8 & 40.8 & 2.1 & & & \\
\hline d 38 & 41.2 & 42.1 & 1.2 & & & \\
\hline NDF intake, $\mathrm{kg} / \mathrm{d}$ & & & & 0.57 & $<0.0001$ & 0.16 \\
\hline
\end{tabular}

${ }^{1}$ Trt $=$ treatment; Trt $\times$ time $=$ treatment $\times$ time interaction.

(Table 5). It has been suggested that mixing PG with a TMR, as was done in the current study, is not effective in altering blood metabolite levels (Grummer et al., 1994; Cozzi et al., 1996). Additionally, blood metabolite concentrations represent only a very specific point in time, and might not necessarily reflect whole-body metabolite production. Across treatments, blood glucose, insulin, NEFA, and BHBA concentrations changed with time. Blood glucose (Figure 1) decreased as calving approached, with the lowest concentration being attained at wk 1 postpartum. Thereafter, blood glucose gradually increased, but concentrations remained lower $(P<0.001)$ postcalving than precalving. This is similar to observations by Vazquez-Añon et al. (1994), who reported a $25 \%$ decrease in blood glucose at wk 1 postpartum, followed by a gradual increase during wk
2 postpartum. The lower blood glucose concentration in early lactation is related to a greater demand for glucose for milk lactose synthesis that is coupled with a reduced availability of diet-derived gluconeogenic precursors as a result of low DMI (Doepel et al., 2002).

Blood insulin concentrations gradually decreased as calving approached, and remained low from wk 1 to 6 postpartum (Figure 1), a trend similar to that reported by others (Doepel et al., 2002). Low blood insulin concentration postpartum allows an increase in body fat mobilization (Bauman and Currie, 1980). Across dietary treatments, blood NEFA concentrations increased $(P=0.01)$ at calving and remained elevated until wk 3 postpartum, and then gradually decreased (Figure 2). Blood BHBA concentrations also increased $(P=0.006)$ dramatically from wk -1 to wk 1 and then 
Table 5. The effect of propylene glycol (PG) administration on blood metabolites in transition dairy cows

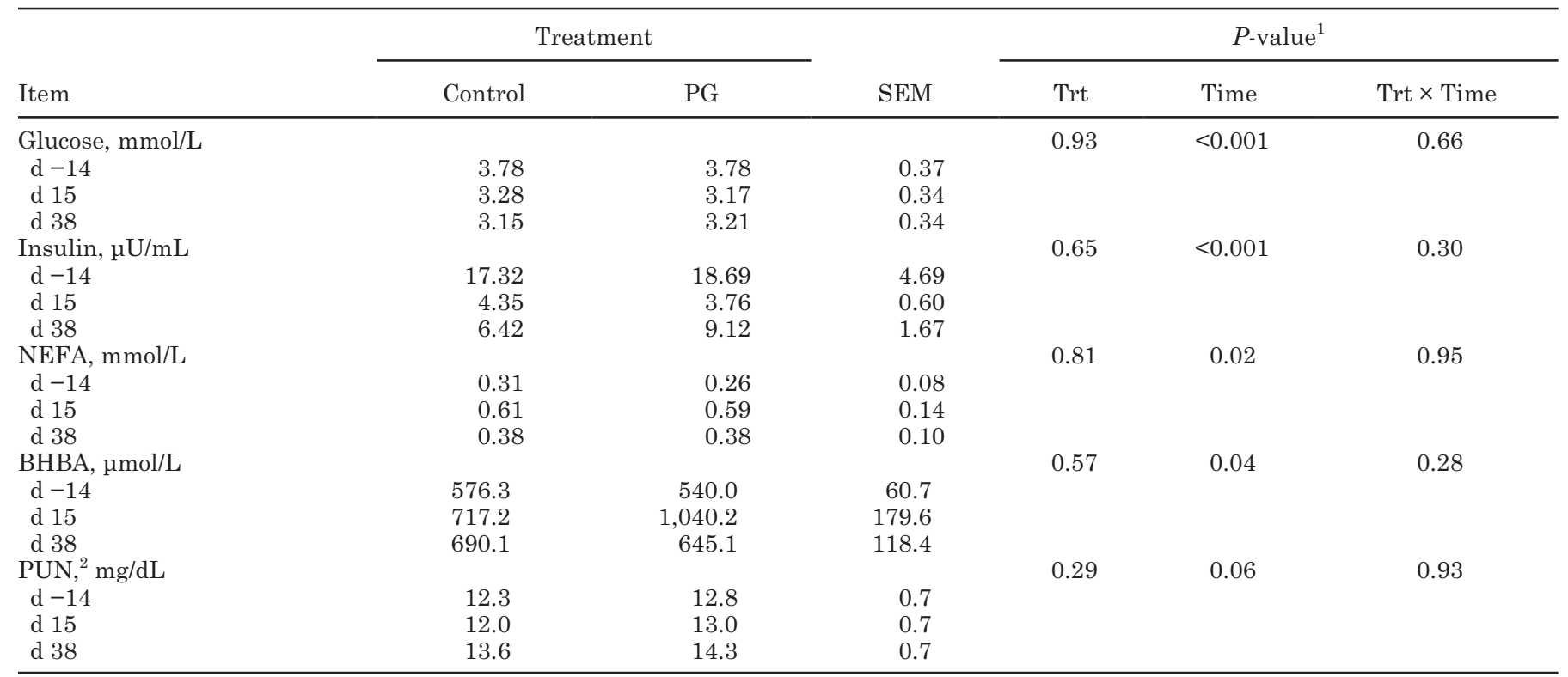

${ }^{1}$ Trt $=$ treatment; Trt $\times$ Time $=$ treatment $\times$ time interaction.

${ }^{2} \mathrm{PUN}=$ plasma urea nitrogen.

remained elevated until wk 6 (Figure 2). Similar changes in both NEFA and BHBA concentrations have been observed in periparturient cows (Vazquez-Añon et al., 1994; Doepel et al., 2002). Across dietary treatments, PUN concentrations (Figure 3) decreased as calving approached and then gradually increased postpartum. The increase in PUN postpartum could have been a result of an increase in DMI postpartum, because PUN is positively correlated to DMI and CP content of a diet (Broderick and Clayton, 1997).

Propylene glycol supplementation had no effect on milk yield $(P=0.36)$, milk fat content $(P=0.50)$, milk fat yield $(P=0.81)$, milk protein content $(P=0.11)$, milk protein yield $(P=0.13)$, milk lactose content $(P$ $=0.52)$, milk lactose yield $(P=0.52)$, and MUN $(P=$ 0.74) (Table 6). Supplementing dairy cows with $\mathrm{PG}$ does not generally increase milk production or alter milk composition (Nielsen and Ingvartsen, 2004). Milk fat content tended to decrease $(P=0.06)$ with time, and these changes are consistent with established changes in milk production and composition that occur as lactation progresses (Stanton et al., 1992).

A major objective of the present study was to delineate the effects of pre- and postpartum PG supplementation on body protein metabolism and gene expression profiles for the major protein degradation pathways in skeletal muscle. Whole-body $\mathrm{N}$ balance, body protein content, urinary 3-MH excretion, and transcript abundance profiles for the major protein degradation systems were used as gross indices of body protein metabolism. Urinary excretion of 3-MH is a commonly used indicator of the extent of myofibrillar protein degradation (Vissers et al., 2003), and an elevation in urinary 3-MH excretion has been taken to be indicative of an increase in the breakdown of myofibers in skeletal muscle (Plaizier et al., 2000b). Various protein degradation systems in skeletal muscle have been characterized, including the lysosomal system, the caspase system, the $\mathrm{Ca}^{2+}$-dependent system, and the ubiquitin-mediated, ATP-dependent system. The $\mathrm{Ca}^{2+}$. dependent system, whose major players are $\mu$ - and $\mathrm{m}$ calpain, and the ubiquitin-mediated, ATP-dependent system, whose key components include ubiquitin, 14$\mathrm{kDa}$ E2, and proteasome 26S subunit, ATPase, have been demonstrated to be the predominant proteolytic pathways for skeletal muscle protein catabolism (Goll et al., 2008). In the present study, we measured the abundance of mRNA sequences that encode for these major proteolytic systems. In lactating sows, a greater mRNA abundance for key components of the ubiquitinmediated, ATP-dependent pathway was associated with increased muscle protein catabolism (Clowes et al., 2005), so we assumed that mRNA abundance would be a valid indirect indicator of muscle proteolysis in dairy cows.

Feeding PG had no effects on most of the major indices of body protein metabolism that were measured, including $\mathrm{N}$ excretion $(P \geq 0.33), \mathrm{N}$ retention $(P=0.74)$, and urinary excretion of $3-\mathrm{MH}(P=0.16$; Table 7), and empty body protein $(P=0.36$; Table 8$)$. Propylene glycol supplementation had no effect $(P=$ 0.96) on $\mathrm{m}$-calpain expression, but it lowered $(P=0.02)$ 

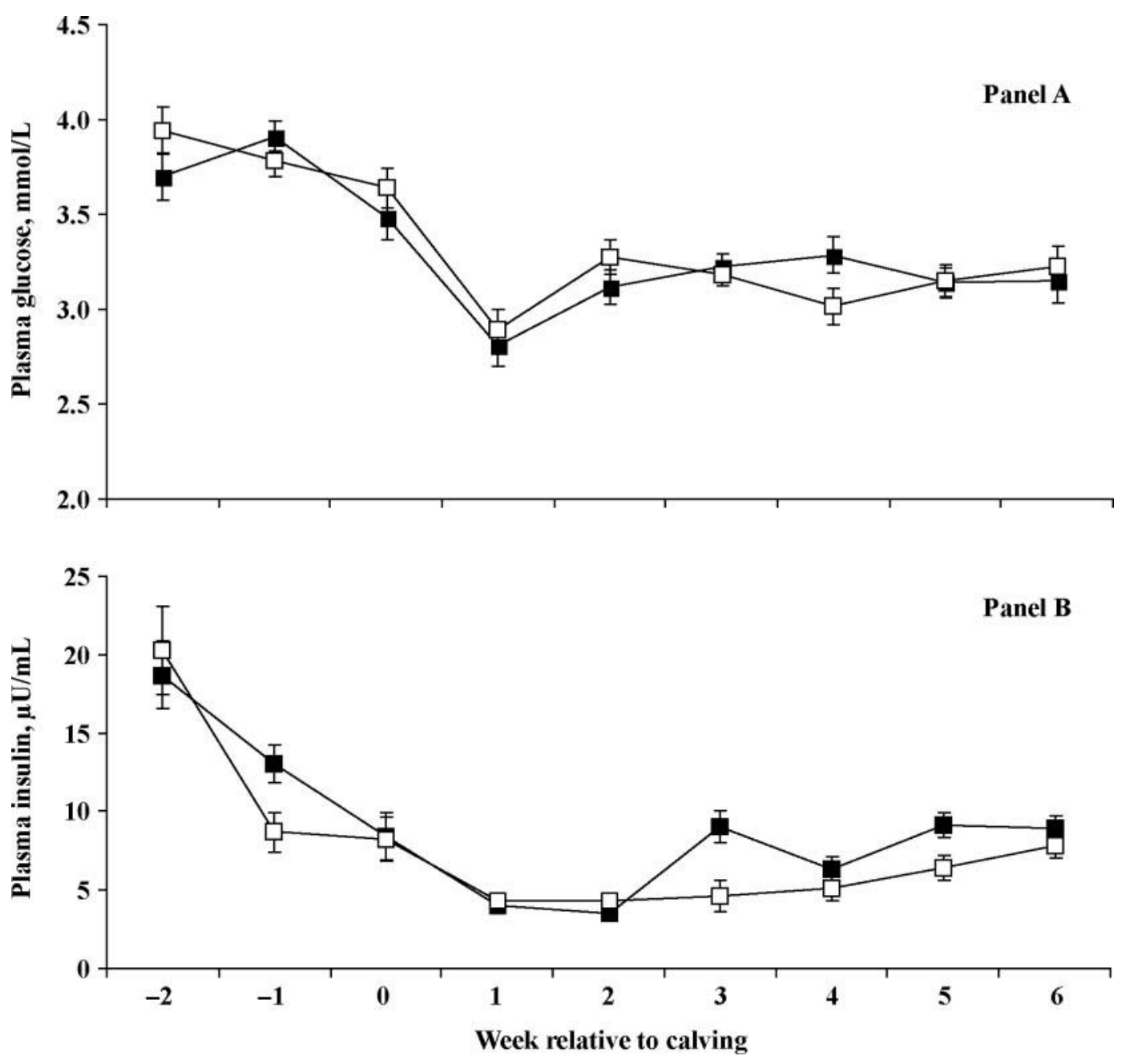

Figure 1. Plasma glucose (panel A) and insulin (panel B) concentrations from d -14 to $\mathrm{d} 42$ relative to calving in cows fed the control ( $\square$ ) or control plus propylene glycol (๘) diets. Each bar represents mean $\pm \mathrm{SEM}$.

$\mu$-calpain expression at d 15 (Figure 4). Supplementing pre- and postpartum diets with PG tended $(P=0.07)$ to downregulate ubiquitin expression with time (Figure $5)$, as ubiquitin expression was reduced $(P=0.02)$ at $\mathrm{d}$ 15 relative to calving. Propylene glycol supplementation also tended $(P=0.06)$ to downregulate proteasome 26S subunit ATPase expression, and was numerically lower $(P=0.08)$ at $\mathrm{d} 15$. Propylene glycol supplementation had no effect on 14-kDa E2 expression; however, $14-\mathrm{kDa}$ E2 expression was lower at d 38 compared with d $15(P<0.05$; Figure 5).

We had hypothesized that body protein loss during early lactation in dairy cows could be attenuated by administering PG in pre- and postpartum diets, a response that would be mediated via an increase in glucose (energy) supply; however, most of our results do not lend support to this hypothesis. Several factors could have influenced the metabolic responses to feed- ing PG. During the transition period, the magnitude of the negative energy balance can be large. Based on observed DMI (Table 4) and calculated $\mathrm{NE}_{\mathrm{L}}$ values of the diet fed (Table 1), the variation in $\mathrm{NE}_{\mathrm{L}}$ intake in the current study was approximately $3.43 \mathrm{Mcal} / \mathrm{d}$, which was greater than the estimated energy contribution of PG (2.83 Mcal/d). Therefore, the PG dose used in this study might have failed to substantially improve the energy status of the dairy cows, given the magnitude of the negative energy balance and variation in $\mathrm{NE}_{\mathrm{L}}$ intake. Also, it is noteworthy that, numerically, PG-fed cows consumed 0.4 to $2.1 \mathrm{~kg} / \mathrm{d}$ less DM compared with control cows, such that NEI, which included the energy contribution of $\mathrm{PG}$ in PG-fed cows, was unaffected $(P=0.44$; Table 8$)$ by diet. In addition, dietary $\mathrm{NE}_{\mathrm{L}}$ (1.63 Mcal/kg) and CP (17.3\%) were above NRC (2001) recommendations during the prepartum phase of the experiment. Possibly, carryover effects from feeding 

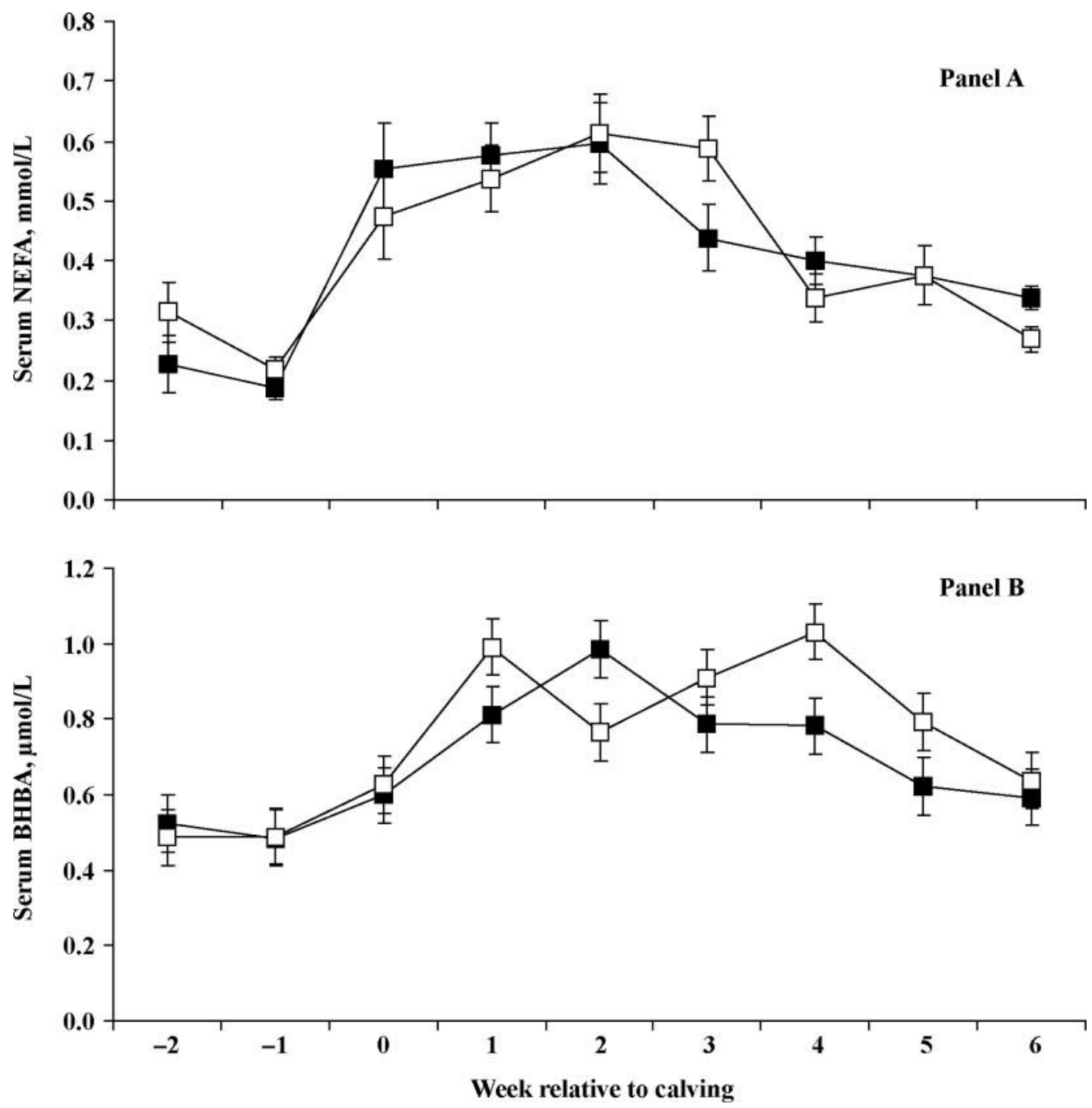

Figure 2. Serum NEFA (panel A) and BHBA (panel B) concentrations from d -14 to d 42 relative to calving in cows fed the control ( $\square$ ) or control plus propylene glycol (ם) diets. Each bar represents mean \pm SEM.

an energy- and CP-dense diet during the close-up dry period might have masked any positive metabolic responses to feeding PG; however, it is noteworthy that the prepartum phase was only $7 \mathrm{~d}$ long, much shorter than prepartum periods of 21 to $28 \mathrm{~d}$ used in other studies (McNamara et al., 2003; Phillips et al., 2003), and we surmise that any effects of prepartum diet on responses to PG supplementation were minimal. The lack of any beneficial response in energy balance in the current study could also be related to the method of $\mathrm{PG}$ administration. When PG is administered via TMR, as in the current study, its absorption is related to the rate at which the feed is consumed. It is possible that under these conditions, the amount of PG absorbed was too low to elicit any metabolic changes. A lack of effect of PG feeding on key plasma metabolites, particularly glucose, NEFA, and BHBA (indicators of energy status) likely indicates that PG supplementation did not alter energy supply.

The tendency of PG to reduce ubiquitin and proteasome 26S subunit, ATPase expression suggests that PG supplementation in pre- and postpartum diets could potentially reduce the loss of body protein during early lactation; however, these results are inconsistent with our observations on the effects of dietary PG supplementation on body protein loss, $\mathrm{N}$ balance, and urinary 3-MH excretion. We do not have a novel explanation of why this was the case; however, given that transcript abundance measurement occurs at the molecular level, it could be more sensitive in detecting 
Table 6. The effect of propylene glycol (PG) administration on milk production and composition in transition dairy cows

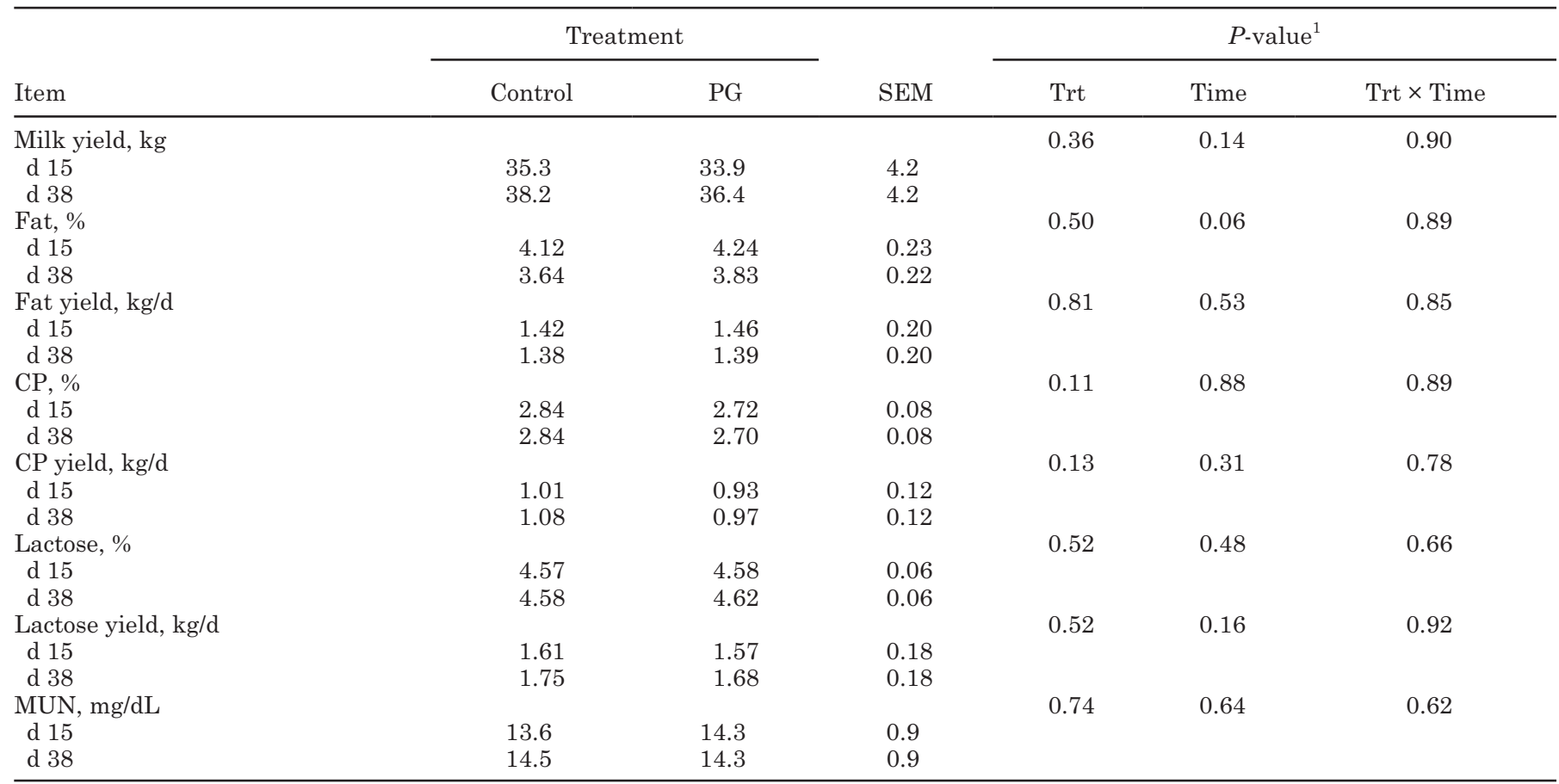

${ }^{1}$ Trt $=$ treatment; Trt $\times$ Time $=$ treatment $\times$ time interaction.

the changes in body protein metabolism compared with the other indirect measurements, which occur at the organismal level.

A major contribution of the present study is the characterization of the transitional changes in body protein metabolism and gene expression profiles for the major protein degradation pathways that occur around calv- ing, as this knowledge is important to enhance our understanding of the mechanisms involved in biochemical adaptations that occur at this time. Nitrogen retention was positive at $d-14$ (Table 6). This is in contrast to the study by Maltz and Silanikove (1996), where they found $\mathrm{N}$ balance to be negative at 2 wk prepartum. However, Plaizier et al. (2000a) reported a positive $\mathrm{N}$ retention

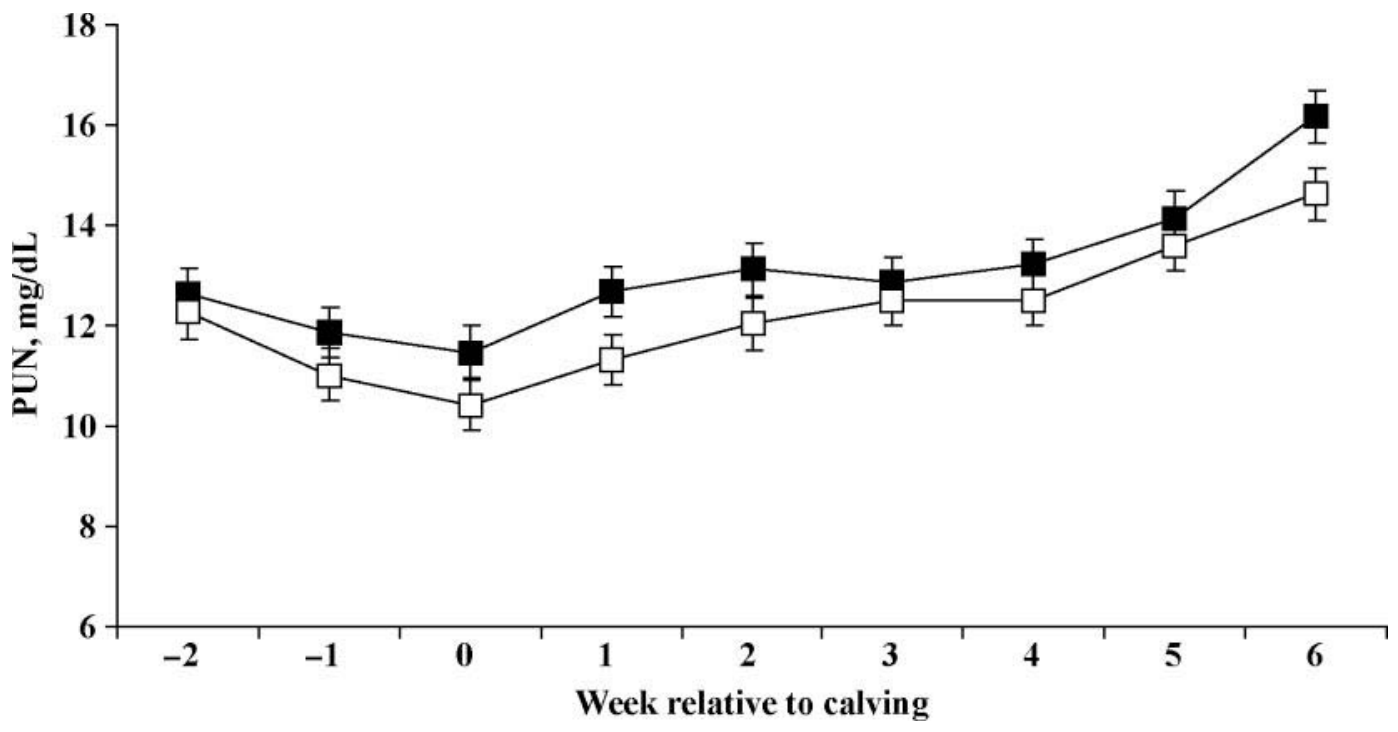

Figure 3. Plasma urea nitrogen (PUN) concentrations from d -4 to d 42 relative to calving in cows fed the control ( $\square$ ) or control plus propylene glycol (₫) diets. Each bar represents mean \pm SEM. 
Table 7. The effect of propylene glycol (PG) administration on $\mathrm{N}$ balance and urinary excretion of 3-methylhistidine (3-MH) in transition dairy cows

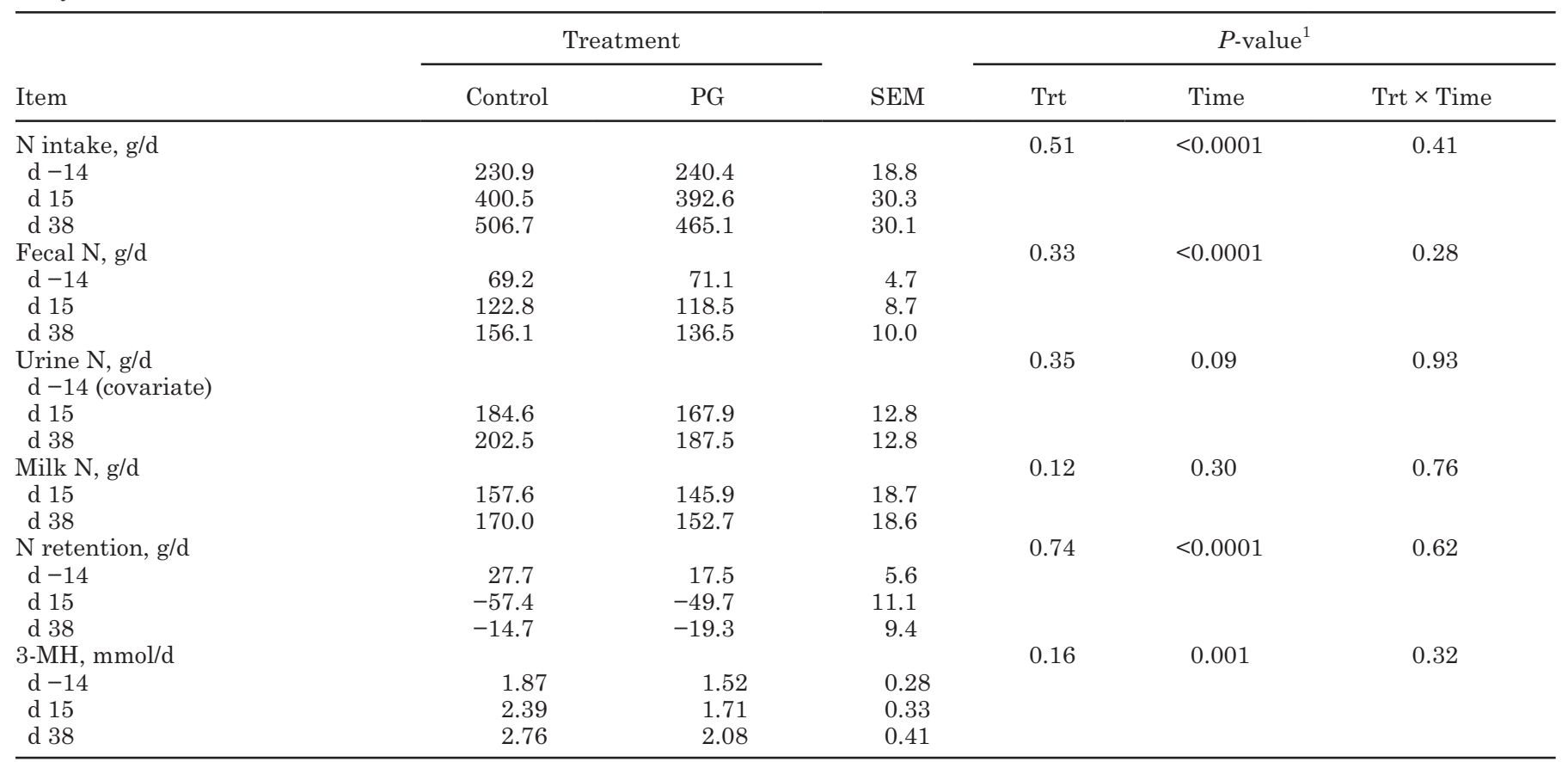

${ }^{1}$ Trt $=$ treatment; Trt $\times$ Time $=$ treatment $\times$ time interaction.

around $\mathrm{d} 3$ to 10 before calving, and their $\mathrm{N}$ retention data are comparable to those obtained in the current study. Postpartum, the negative $\mathrm{N}$ balance values in the current study were in the range reported by Maltz and Silanikove (1996). As expected, N balance was more negative at $\mathrm{d} 15$ than at $\mathrm{d} 38(P<0.05$; Table 6$)$. A negative $\mathrm{N}$ balance during early lactation is a result of a nutrient deficit, which leads to the mobilization of body protein to support milk production (Plaizier et al., 2000a). This nutrient deficit is transient and, as lactation progresses, $\mathrm{N}$ intake increases and body protein catabolism diminishes, thereby restoring a positive $\mathrm{N}$ balance (Plaizier et al., 2000a).

Body protein content was lower at d 15 compared with $\mathrm{d}-14(P<0.001)$ but only numerically lower $(P$ $=0.07)$ at $\mathrm{d} 38$ compared with $\mathrm{d} 15$ (Table 8). Other studies (Komaragiri and Erdman, 1997) observed similar changes whereby the depletion of body protein reserves is restricted, with repletion occurring by wk 5 postpartum, while body fat mobilization continues for an extended period. In the present study, the estimated loss of body protein was $14 \mathrm{~kg}$ from d -14 to $\mathrm{d} 38$, which is in close agreement with the findings of Komaragiri and Erdman (1997) and Komaragiri et al. (1998), who reported body protein mobilization of 12 to $21 \mathrm{~kg}$ by wk 5 postpartum. However, a more recent study with dairy cows (Phillips et al., 2003) reported a body protein loss of $8 \mathrm{~kg}$ from $\mathrm{d}-14$ to $\mathrm{d} 60$, which is lower than the body protein loss that we observed over a shorter period (d 14 to 38). Urinary excretion of 3-MH was lower at $d-14$ than at $d 15$ and $38(P<0.05$; Table 6$)$. The elevation in urinary $3-\mathrm{MH}$ excretion postpartum suggests an increase in the breakdown of myofibers in skeletal muscle (Motyl and Barej, 1986; Plaizier et al., 2000b). Urinary 3-MH excretion at d 15 was not different from d 38. In a study by Tamminga et al. (1997), there was an increase in catabolism of body protein up to wk 4 after calving; however, by wk 5 postpartum, there was protein accretion. Therefore, the reduction in skeletal muscle breakdown as lactation progresses should also lead to a reduction in urinary excretion of 3-MH (Plaizier et al., 2000b). Not surprisingly, a significant inverse relationship was found between body protein content and urinary 3-MH excretion $(\mathrm{r}=-0.97$; $P=0.011$ )

As expected, time influenced mRNA abundance for most components of the protein degradation pathways. Expression of m-calpain was upregulated at d 15 ( $P$ $=0.02$ ) compared with $\mathrm{d}-14$, before being downregulated to precalving levels by d 38 (Figure 4). Similarly, $\mu$-calpain was upregulated at d $15(P=0.005)$, before being downregulated to precalving levels by d 38 (Figure 4). Other studies have shown an increase in m-calpain expression during muscle wasting in rats (Voisin et al., 1996) and humans (Mansoor et al., 1996), and $\mu$ - and $\mathrm{m}$-calpain expression in rainbow trout (Salem et al., 2004). The increase in $\mu$ - and $m$-calpain expression at d 15 relative to calving coincided with elevated urinary 
Table 8. The effect of propylene glycol (PG) administration on body composition and energy balance in transition dairy cows ${ }^{1}$

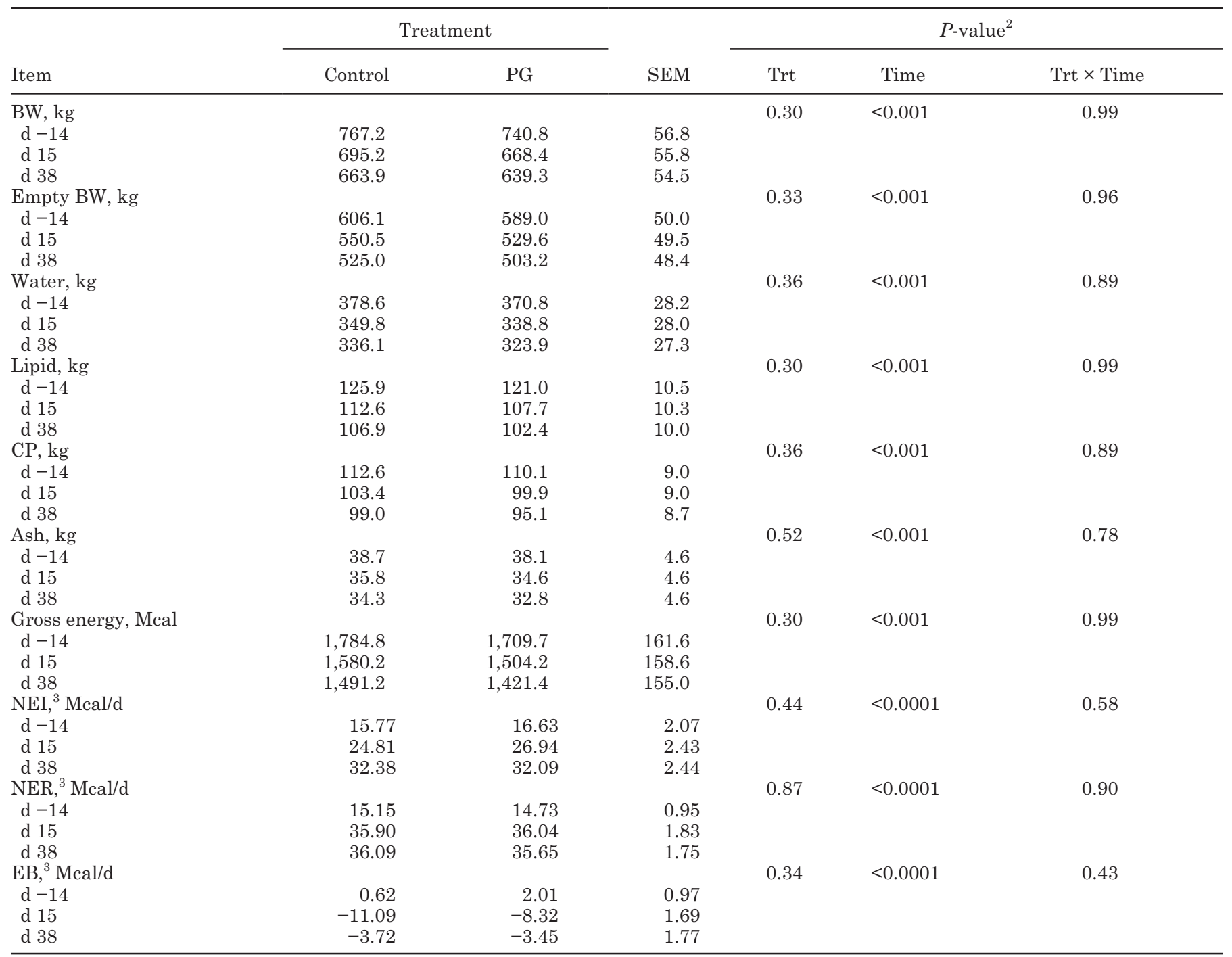

${ }^{1}$ Body composition was determined using the urea dilution technique (Agnew et al., 2005).

${ }^{2}$ Trt $=$ treatment; Trt $\times$ Time $=$ treatment $\times$ time interaction.

${ }^{3} \mathrm{NEI}=$ net energy intake (calculated as average daily DMI $\times$ the calculated $\mathrm{NE}_{\mathrm{L}}$ value of the diet; for PG-fed cows, this included estimated energy contribution of $\mathrm{PG}$ ), NER = net energy requirement [for prefresh cows, $\mathrm{NER}$ was calculated as $\mathrm{NE}_{\mathrm{M}}+$ net energy for pregnancy $\left(\mathrm{NE}_{\mathrm{P}}\right)$, where $\mathrm{NE}_{\mathrm{M}}$ and $\mathrm{NE}_{\mathrm{P}}(\mathrm{Mcal} / \mathrm{d})$ were calculated using $\mathrm{NRC}$ [2001] equations. For lactating cows, $\mathrm{NER}$ was calculated as $\mathrm{NE}_{\mathrm{M}}+\mathrm{NE}_{\mathrm{L}}$; $\mathrm{NE}_{\mathrm{L}}$ $(\mathrm{Mcal} / \mathrm{d})$ was calculated as $(9.29 \times$ fat yield $/ \mathrm{d})+(5.71 \times$ protein yield/d $)+(3.95 \times$ lactose yield $/ \mathrm{d}) ; \mathrm{EB}=$ energy balance $($ calculated as $\mathrm{NEI}-$ NER).

3-MH excretion, which is likely indicative of increased body protein catabolism. In the present study, mRNA abundance of calpastatin, a specific inhibitor of both $\mu$ - and m-calpain (Goll et al., 2008), was not measured; therefore, we cannot entirely discount the possibility that a downregulation in calpastatin gene expression could have allowed upregulation of $\mu$ - and $\mathrm{m}$-calpain activity in skeletal muscle.

There was a $22 \%$ increase $(P=0.63)$ in mRNA abundance for ubiquitin at d 15 compared with $d-14$ (Figure 5). However, mRNA abundance for ubiquitin tended $(P=0.07)$ to be lower at d 38 compared with $\mathrm{d}$
15. Messenger RNA abundance for $14-\mathrm{kDa} \mathrm{E} 2$ was $55 \%$ greater $(P=0.22)$ at $\mathrm{d} 15$ than at $\mathrm{d}-14$; however, 14$\mathrm{kDa}$ E2 abundance was lower at d 38 compared with d $15(P=0.005)$. The increase in ubiquitin and $14-\mathrm{kDa}$ E2 expression at d 15 suggests that muscle protein degradation was stimulated, a suggestion that is supported by the observed negative $\mathrm{N}$ balance, elevated urinary 3-MH excretion, and low body protein content during early lactation. In agreement with our observations, Clowes et al. (2005) reported marked increases in mRNA abundance for several key components of the ubiquitin-mediated, ATP-dependent pathway, in- 

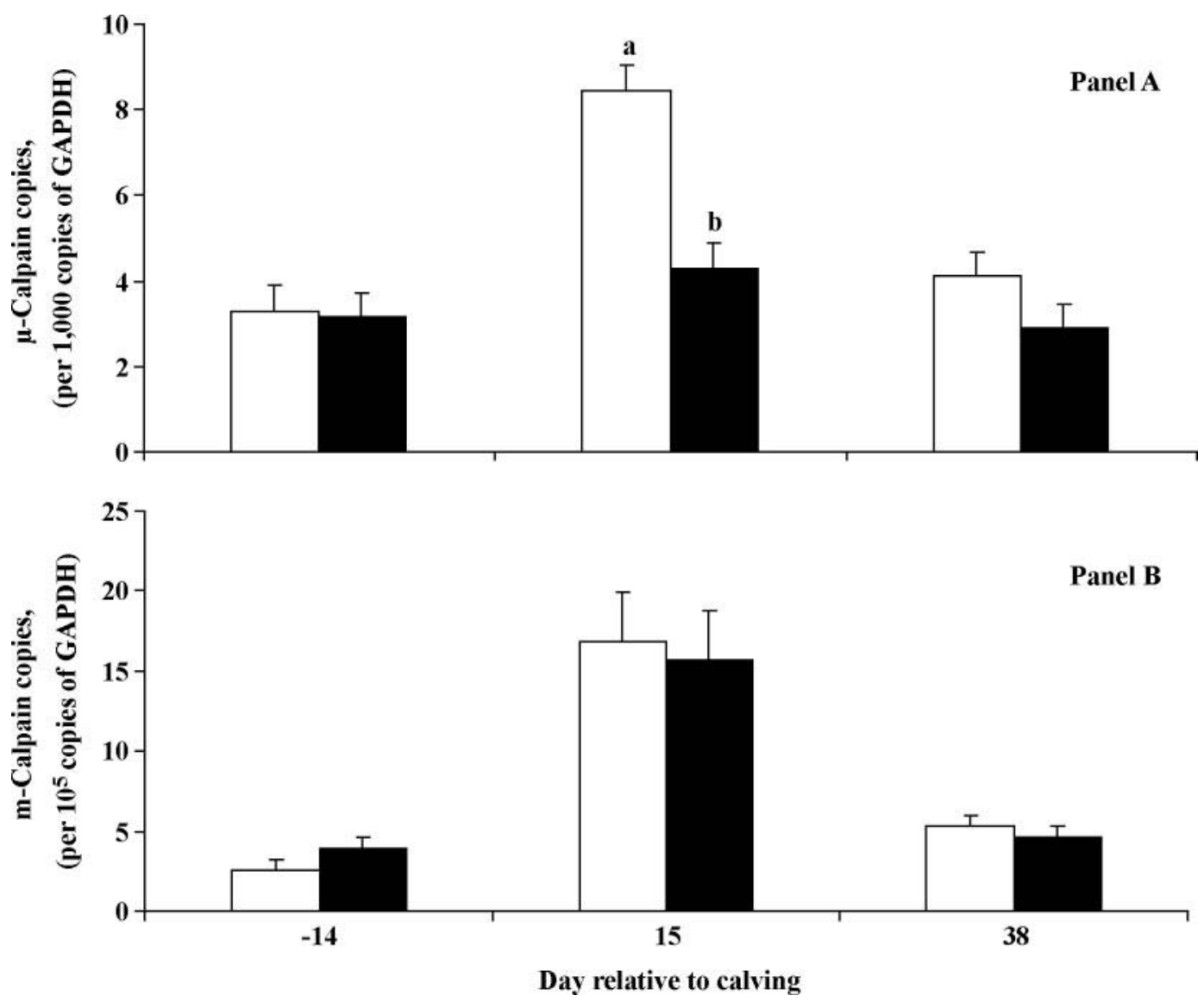

Figure 4. Levels of mRNA for $\mu$-calpain (panel A) and m-calpain (panel B) in cows fed the control (open bars) or control plus propylene glycol (PG; solid bars) diets. Level of $\mu$-calpain mRNA was lower at d 15 in cows fed PG compared with control cows. Across dietary treatments, levels of $\mu$-calpain $(P=0.003)$ and $\mathrm{m}$-calpain $(P=0.02)$ mRNA were greater at d 15 compared with $\mathrm{d}-14$ and $\mathrm{d} 38$. Each bar represents mean \pm SEM.

cluding ubiquitin and 14-kDa E2, in skeletal muscle of sows during early lactation. Upregulation of this ubiquitin-mediated, ATP-dependent pathway has been demonstrated to occur under numerous catabolic states that involve protein degradation, including metabolic acidosis in dairy cows (Mutsvangwa et al., 2004). Although the mRNA abundance of ubiquitin and 14-kDa E2 changed with time, there was no effect of time on proteasome $26 \mathrm{~S}$ subunit, ATPase expression. All components of the ubiquitin-dependent system are involved in various steps that regulate this pathway, but their relative importance in these regulatory steps has not been elucidated (Attaix et al., 1998). Therefore, the physiological importance of the lack of response in mRNA abundance for the proteasome $26 \mathrm{~S}$ subunit, ATPase in parallel with the changes in mRNA abundance for the other components of the system, is unknown. Mutsvangwa et al. (2004) also reported inconsistent changes in mRNA abundance of components of this pathway in acidotic dairy cows.
Across dietary treatments, empty BW (EBW) and its components changed with time (Table 7), and these changes were larger $(P<0.05)$ between $\mathrm{d}-14$ and $\mathrm{d} 15$, compared with between $d 15$ and 38 (data not shown). As expected, there was a reduction in BW at d $15(P<0.01)$ and $d 38(P<0.01)$ compared with $d-14$. The change in BW between $d-14$ and $d 15$ includes the weight of the calf. On average, cows lost $102 \mathrm{~kg}$ of BW from d -14 to d 38. This is in agreement with an average loss of 98 $\mathrm{kg}$ of BW during the same period from 2 wk prepartum to 5 wk postpartum (Komaragiri et al., 1998). Changes in EBW paralleled those in BW, with an average EBW loss of $83 \mathrm{~kg}$. Body lipid content decreased $(P<0.001)$ by $19 \mathrm{~kg}$ from $\mathrm{d}-14$ to $\mathrm{d} 38$, which was within the range of 15 to $60 \mathrm{~kg}$ reported by Chilliard et al. (1991) but was lower than that observed in other studies (Komaragiri and Erdman, 1997; Komaragiri et al., 1998). The initial lipid content in the cows used in studies by Komaragiri and Erdman (1997) and Komaragiri et al. (1998) ranged from 143 to $159 \mathrm{~kg}$, compared with $123 \mathrm{~kg}$ in 

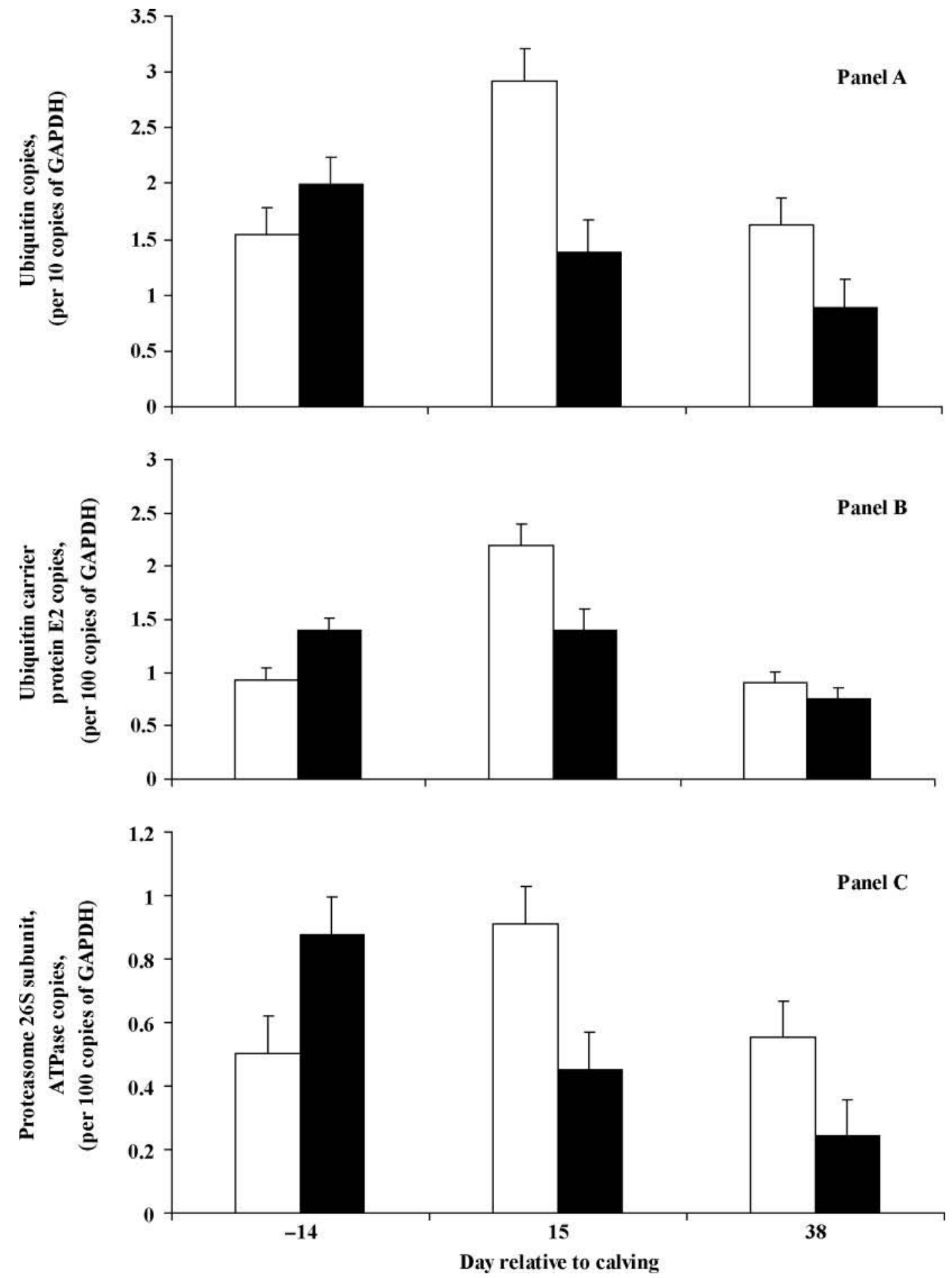

Figure 5. Levels of mRNA for ubiquitin (panel A), ubiquitin-carrier protein E2 (panel B), and proteasome 26S subunit, ATPase (panel C) in cows fed the control (open bars) or control plus propylene glycol (PG; solid bars) diets. Levels of ubiquitin mRNA tended to be lower ( $P=$ $0.07)$ at $d 15$ in cows fed PG compared with control cows. Levels of proteasome 26S subunit, ATPase mRNA tended to be lower $(P=0.097)$ at $\mathrm{d} 38$ in cows fed PG compared with control cows. Across dietary treatments, levels of mRNA for 14-kDa ubiquitin-carrier protein E2 were lower $(P=0.005)$ at $\mathrm{d} 38$ compared with $\mathrm{d} 15$. Each bar represents mean \pm SEM. 
the present study. Additionally, the milk production in these studies averaged $41 \mathrm{~kg} / \mathrm{d}$, which was greater than the $36 \mathrm{~kg} / \mathrm{d}$ observed in the current study. Body fat mobilization is a function of body fat reserves and milk production, among other factors, because body fat mobilization is positively correlated to body fat reserves at calving, and milk production during the subsequent lactation (Komaragiri and Erdman, 1997). Therefore, the lower estimated loss of $19 \mathrm{~kg}$ in this study could be due to the lower body fat reserves prepartum and a lower level of milk production compared with previous studies (Komaragiri and Erdman, 1997; Komaragiri et al., 1998).

As expected, body gross energy (GE) content was greater at $\mathrm{d}-14$ than at $\mathrm{d} 15(P<0.001)$ and $\mathrm{d} 38(P$ $<0.001$ ) (Table 8), indicating mobilization of body fat and protein to meet nutrient demands for milk production as lactation progresses. The change in body GE content was $-291 \mathrm{Mcal}$, and was in the range of -258 to -329 Mcal that was reported by Chilliard et al. (1991) during the first $8 \mathrm{wk}$ of lactation. However, Komaragiri and Erdman (1997) reported changes in body GE of -605 Mcal during the same period. Among other factors, differences in average milk production in the current study and that of Komaragiri and Erdman (1997) could partly account for the apparent disparity. Across dietary treatments, prepartum $(d-14)$ NEI was slightly greater that NER; consequently, prefresh cows were in a slight positive EB (Table 8). After calving, cows were in a negative $\mathrm{EB}$, which reached a nadir of -8.32 to $-11.09 \mathrm{Mcal} / \mathrm{d}$ at d 15 (Table 8). Negative EB in early lactation is expected, as cows often fail to consume adequate DM to meet nutrient demands for milk production (NRC, 2001). Others (Rastani et al., 2001; Doepel et al., 2002) have reported EB nadir of -12.9 to $-16 \mathrm{Mcal} / \mathrm{d}$ within the first $2 \mathrm{wk}$ of lactation.

\section{CONCLUSIONS}

Results indicate that PG administration had no effect on the major indices of body protein metabolism. The lack of an effect of $\mathrm{PG}$ on body protein, whole-body $\mathrm{N}$ balance, and urinary 3-MH excretion, which are indirect measures of body protein catabolism, indicated that PG supplementation did not reduce mobilization of maternal protein reserves, perhaps, not surprisingly, because PG supplementation did not improve energy status. Before this study, although it was known that there is an increase in skeletal muscle catabolism during the transition period, the exact protein degradation systems involved in this process had not been delineated. A major contribution of the current study is characterization of the transitional changes in mRNA levels for components of the $\mathrm{Ca}^{2+}$-dependent and ubiq- uitin-mediated proteolytic systems in skeletal muscle. Results from this study demonstrated that these proteolytic pathways are upregulated during early lactation, which may increase degradation of skeletal muscle protein. The concomitant changes that were observed in body protein, whole-body $\mathrm{N}$ balance, and urinary $3-\mathrm{MH}$ excretion are consistent with an increase in the degradation of skeletal muscle protein in early lactation. In the current study, only mRNA abundance was measured; however, cellular enzymes can be controlled after transcription. Therefore, further studies in which cellular enzyme concentrations and, more importantly, enzyme activity, are quantified would further improve our knowledge in this area.

\section{ACKNOWLEDGMENTS}

The authors thank Marlene Fehr and staff of the Greenbrae Dairy Research Facility, University of Saskatchewan, for animal care and excellent technical assistance, and Jason Marshall (Department of Animal and Poultry, University of Saskatchewan) for excellent technical assistance with real-time qPCR analyses. This research was supported by the Natural Sciences and Engineering Research Council of Canada (NSERC).

\section{REFERENCES}

Agnew, R. E., T. Yan, W. J. McCaughey, J. D. McEvoy, D. C. Patterson, M. G. Porter, and R. W. J. Steen. 2005. Relationships between urea dilution measurements and body weight and composition of lactating dairy cows. J. Dairy Sci. 88:2476-2486.

AOAC. 1990. Official Methods of Analysis. 15th ed. Assoc. Off. Anal. Chem., Arlington, VA.

Attaix, D., E. Aurousseau, L. Combaret, A. Kee, D. Larbaud, C. Ralliere, B. Souweine, D. Taillandier, and T. Tilignac. 1998. Ubiquitin-proteasome-dependent proteolysis in skeletal muscle. Reprod. Nutr. Dev. 38:153-165.

Bauman, D. E., and B. W. Currie. 1980. Partitioning of nutrients during pregnancy and lactation: A review of mechanisms involving homeostasis and homeorhesis. J. Dairy Sci. 63:15141529.

Brockman, R. P. 1979. Glucagon responses to exercise in sheep. Aust. J. Biol. Sci. 32:215-220.

Broderick, G. A., and M. K. Clayton. 1997. A statistical evaluation of animal and nutritional factors influencing concentrations of milk urea nitrogen. J. Dairy Sci. 80:2964-2971.

Canadian Council on Animal Care. 1993. Guide to the Care and Use of Experimental Animals. Vol. 1. CCAC, Ottawa, Ontario, Canada.

Chilliard, Y., M. Cisse, R. Lefaivre, and B. Remond. 1991. Body composition of dairy cows according to lactation stage, somatotropin treatment, and concentrate supplementation. J. Dairy Sci. 74:3103-3116.

Clowes, E. J., F. X. Aherne, and V. E. Baracos. 2005. Skeletal muscle protein mobilization during the progression of lactation. Am. J. Physiol. Endocrinol. Metab. 288:E564-E572.

Colucci, P. E., L. E. Chase, and P. J. Van Soest. 1982. Feed intake, apparent diet digestibility, and rate of particulate passage in dairy cows. J. Dairy Sci. 65:1445-1456. 
Cozzi, G., P. Berghazi, F. Gottordo, G. Gabai, and I. Andrighetto. 1996. Effects of feeding propylene glycol to mid-lactating dairy cows. Anim. Feed Sci. Technol. 64:43-51.

DeFrain, J. M., A. R. Hippen, K. F. Kalscheur, and R. S. Patton. 2005. Effects of feeding propionate and calcium salts of longchain fatty acids on transition dairy cow performance. J. Dairy Sci. 88:983-993.

Doepel, L., H. Lapierre, and J. J. Kennelly. 2002. Peripartum performance and metabolism of dairy cows in response to prepartum energy and protein intake. J. Dairy Sci. 85:23152334.

Drackley, J. K. 1999. Biology of dairy cows during the transition period: The final frontier? J. Dairy Sci. 82:2259-2273.

Drackley, J. K., T. R. Overton, and G. N. Douglas. 2001. Adaptations of glucose and long-chain fatty acid metabolism in liver of dairy cows during the periparturient period. J. Dairy Sci. 84(E Suppl.):E100-E112.

Erdman, R. A., and S. M. Andrew. 1989. Methods for and estimates of body tissue mobilization in the lactating dairy cow. Page 19 in Proc. Monsanto Tech. Symp. preceding Cornell Nutr. Conf. Feed Manuf., Syracuse, NY. Monsanto Co., St. Louis, MO.

Goll, D. E., G. Neti, S. W. Mares, and V. F. Thompson. 2008 Myfibrillar protein turnover: The proteasome and the calpains. J. Anim. Sci. 86(E Suppl.):E19-E35.

Greenwood, F. C., W. M. Hunter, and J. S. Glover. 1963. The preparation of 131I-labelled human growth hormone of high specific radioactivity. Biochem. J. 89:114-123.

Grummer, R. R. 1993. Etiology of lipid-related metabolic disorders in periparturient dairy cows. J. Dairy Sci. 76:3882-3896.

Grummer, R. R., J. C. Winkler, S. J. Bertics, and V. A. Studer. 1994. Effect of propylene glycol dosage during feed restriction on metabolites in blood of prepartum Holstein heifers. J. Dairy Sci. 77:3618-3623.

Guo, H., W.-S. Liu, A. Takasuga, K. Eyer, E. Landrito, S.-Z. Xu, X. Gao, and H.-Y. Ren. 2005. Mapping of the CCK, PSMC2, PSMC4, PSMC1, CPB1 and PSPH genes in cattle. Anim. Genet. 37:7289.

Juszczuk-Kubiak, E., T. Sakowski, K. Flisikowski, K. Wicińska, J. Oprządek, and S. J. Rosochacki. 2004. Bovine $\mu$-calpain (CAPN1) gene: New SNP within intron 14. J. Appl. Genet. 45:457-460.

Komaragiri, M. V. S., D. P. Casper, and R. A. Erdman. 1998. Factors affecting body tissue mobilization in early lactation dairy cows. 2. Effect of dietary fat on mobilization of body fat and protein. J. Dairy Sci. 81:169-175.

Komaragiri, M. V. S., and R. A. Erdman. 1997. Factors affecting body tissue mobilization in early lactation dairy cows. 1. Effect of dietary protein on mobilization of body fat and protein. J. Dairy Sci. 80:929-937.

Lomax, M. A., and G. D. Baird. 1983. Blood flow and nutrient exchange across the liver and gut of the dairy cow. Effects of lactation and fasting. Br. J. Nutr. 49:481-496.

Maltz, E., and N. Silanikove. 1996. Kidney function and nitrogen balance of high yielding dairy cows at the onset of lactation. J. Dairy Sci. 79:1621-1626.

Mansoor, O., B. Beaufrere, Y. Boirie, C. Ralliere, D. Taillandier, E. Aurousseau, P. Schoeffler, M. Arnal, and D. Attaix. 1996. Increased mRNA levels for components of the lysosomal, $\mathrm{Ca}^{2+}$. activated, and ATP-ubiquitin-dependent proteolytic pathways in skeletal muscle from head trauma patients. Proc. Natl. Acad. Sci. USA 93:2714-2718.

McNamara, S., F. P. O’Mara, M. Rath, and J. J. Murphy. 2003. Effects of different transition diets on dry matter intake, milk production, and milk composition in dairy cows. J. Dairy Sci. 86:2397-2408

Meijer, G. A. L., J. van der Meulen, J. G. M. Bakker, C. J. van der Koelen, and A. M. van Vuuren. 1995. Free amino acids in plasma and muscle of high yielding dairy cows in early lactation. J. Dairy Sci. 78:1131-1141.

Mena, A., X. P. Ioannou, A. Van Kessel, S. Van Drunen Little-Van Den Hurk, Y. Popowych, L. A. Babiuk, and D. L. Godson. 2002.
Th1/Th2 biasing effects of vaccination in cattle as determined by real-time PCR. J. Immunol. Methods 263:11-21.

Min, S., Y. Yisheng, and Y. Lu. 1992. Determination of urinary 3-methylhistidine by high-performance liquid chromatography with o-phthaldialdehyde precolumn derivatization. J. Chromatogr. 581:272-276.

Miyoshi, S., J. L. Pate, and D. L. Palmquist. 2001. Effects of propylene glycol drenching on energy balance, plasma glucose, plasma insulin, ovarian function and conception in dairy cows. Anim. Reprod. Sci. 68:29-43.

Motyl, T., and W. Barej. 1986. Plasma amino acid indices and urinary 3 -methyl histidine excretion in dairy cows in early lactation. Ann. Rech. Vet. 17:153-157.

Mutsvangwa, T., J. Gilmore, J. E. Squires, M. I. Lindinger, and B. W. McBride. 2004. Chronic metabolic acidosis increases mRNA levels for components of the ubiquitin-mediated proteolytic pathway in skeletal muscle of dairy cows. J. Nutr. 134:558-561.

Nielsen, N. I., and K. L. Ingvartsen. 2004. Propylene glycol for dairy cows: A review of the metabolism of propylene glycol and its effects on physiological parameters, feed intake, milk production and risk of ketosis. Anim. Feed Sci. Technol. 115:191-213.

NRC. 2001. Nutrient Requirements of Dairy Cattle. 7th rev. ed. National Academy Press, Washington, DC.

Phillips, G. J., T. L. Citron, J. S. Sage, K. A. Cummins, M. J. Cecava, and J. P. McNamara. 2003. Adaptations in body muscle and fat in transition dairy cattle fed differing amounts of protein and methionine hydroxy analog. J. Dairy Sci. 86:3634-3647.

Plaizier, J. C., A. Martin, T. F. Duffield, R. Bagg, P. Dick, and B. W. McBride. 2000a. Effect of a prepartum administration of monensin in a controlled-release capsule on apparent digestibilities and nitrogen utilization in transition dairy cows. J. Dairy Sci. 83:2918-2925.

Plaizier, J. C., J. P. Walton, A. Martin, T. Duffield, R. Bagg, P. Dick, and B. W. McBride. 2000b. Effects of monensin on 3 -methylhistidine excretion in transition dairy cows. J. Dairy Sci. 83:2810-2812.

Rastani, R. R., S. M. Andrew, S. A. Zinn, and C. J. Stewart. 2001. Body composition and estimated tissue energy balance in Jersey and Holstein cows during early lactation. J. Dairy Sci. 84:12011209.

Salem, M., J. Nath, C. E. Rexroad, J. Killerfer, and J. Yao. 2004. Identification and molecular characterization of the rainbow trout calpains (Capn1 and Capn2): Their expression in muscle wasting during starvation. Comp. Biochem. Physiol. 140B:63-71.

SAS Institute. 2004. SAS/STAT 9.1 User's Guide. SAS Institute Inc., Cary, NC.

Stanton, T. L., L. R. Jones, R. W. Everett, and S. D. Kachman. 1992. Estimating milk, fat, and protein lactation curves with a test day model. J. Dairy Sci. 75:1691-1700.

Tamminga, S., P. A. Luteijn, and R. G. M. Meijer. 1997. Changes in composition and energy content of liveweight loss in dairy cows with time after parturition. Livest. Prod. Sci. 52:31-38.

Van Soest, P. J., J. B. Robertson, and B. A. Lewis. 1991. Methods for dietary fiber, neutral detergent fiber and non-starch polysaccharides (NSP) in relation to animal nutrition. J. Dairy Sci. 74:3583-3597.

Vazquez-Añon, M., S. Bertics, M. Luck, R. R. Grummer, and J. Pinheiro. 1994. Peripartum liver triglyceride and plasma metabolites in dairy cows. J. Dairy Sci. 77:1521-1528.

Vissers, Y. L. J., M. F. von Meyenfeldt, V. B. Braulio, Y. C. Luiking, and N. E. P. Deutz. 2003. Measuring whole-body actin/myosin protein breakdown in mice using a primed constant stable isotope-infusion protocol. Clin. Sci. 104:585-590.

Voisin, L., D. Breuille, L. Combaret, C. Pouyet, D. Taillander, E. Aurousseau, C. Obled, and D. Attaix. 1996. Muscle wasting in a rat model of long-lasting sepsis results from the activation of lysosomal, $\mathrm{Ca}^{2+}$-activated, and ubiquitin-proteasome proteolytic pathways. J. Clin. Invest. 97:1610-1617. 